\title{
UJI AKTIVITAS SALEP ANTI JERAWAT EKSTRAK ETANOL DAUN BINAHONG (Anredera cordifolia(Ten) Steenis) TERHADAP BAKTERI Propionibacterium acnes
}

\author{
Agung Nur Cahyanta ${ }^{1}$, Nilla Yuliana Ardiyanti ${ }^{2}$ \\ Email : aku.cahyanta@gmail.com \\ ${ }^{12}$ Program Studi S1 Farmasi Sekolah Tinggi Ilmu Kesehatan Bhakti Mandala Husada Slawi, Jl. Cut Nyak \\ Dhien No.16 Kalisapu, Slawi, Kabupaten Tegal Telp/Fax (0283) 6197570
}

\begin{abstract}
Abstrak
Tanaman Binahong (Anredera cordifolia (Ten) Steenis ) merupakan tanaman yang tumbuh menjalar dan memiliki manfaat yang sangat besar dalam dunia pengobatan. Khasiat daun binahong tidak lepas dari kandungan metabolit sekundernya yang meliputi flavonoid, alkaloid, saponin, dan polifenol. Secara empiris daun binahong dapat digunakan untuk mengatasi salah satu penyakit kulit yaitu jerawat. Jerawat merupakan suatu kondisi terjadi penyumbatan kelenjar minyak pada kulit disertai infeksi dan peradangan. Salah satu penyebab terjadinya jerawat adalah bakteri Propionibacterium acnes. Penelitian ini bertujuan untuk mengetahui aktivitas antibakteri salep anti jerawat ekstrak etanol daun binahong dengan konsentrasi 25\%, 30\%, 35\% terhadap bakteri Propionibacterium acnes. Metode ekstraksi yang digunakan dalam penelitian ini adalah metode maserasi dengan pelarut etanol $96 \%$. Uji aktivitas antibakteri menggunakan metode cakram. Analisis data menggunakan One Way ANOVA dan dilanjutkan dengan uji Post Hoc. Berdasarkan uji aktivitas antibakteri, salep ekstrak etanol daun binahong memiliki kemampuan menghambat pertumbuhan Propionibacterium acnes terlihat dengan adanya zona hambat yang terbentuk. Diameter zona hambat pada salep dengan konsentrasi ekstrak 25\% sebesar 17,8 mm, salep dengan konsentrasi 30\% sebesar 19,6 mm, salep dengan konsentrasi 35\% sebesar $22 \mathrm{~mm}$, dan untuk basis salep tidak mempunyai kemampuan dalam menghambat bakteri Propionibacterium acnes. Hasil uji ANOVA diperoleh nilai signifikan $0,000<0,05$, dapat disimpulkan bahwa pada taraf kepercayaan $95 \%$ terdapat perbedaan bermakna antara zona hambat dari masing-masing konsentrasi. Hasil uji lanjut Post Hoc menunjukkan ada perbedaan bermakna aktivitas antara basis dengan formula 1, formula 2, formula 3 karena $\mathrm{P}<0.05$. Hasil pengukuran diameter zona hambat menunjukkan bahwa salep ekstrak etanol daun binahong memiliki daya hambat dengan kriteria kuat sampai dengan sangat kuat terhadap bakteri Propionibacterium acnes.
\end{abstract}

Kata Kunci : Binahong, Salep, Jerawat, Propionibacterium acnes.

\section{Pendahuluan}

Jerawat merupakan salah satu penyakit kulit yang disebabkan karena terjadinya penyumbatan kelenjar minyak pada kulit yang disertai infeksi dan peradangan [1]. Jerawat umumnya muncul pada wajah, tetapi dapat juga muncul pada daerah kepala, punggung, dada, atau lengan atas. Jerawat dapat disebabkan oleh bakteri Propionibacterium acnes ${ }^{[1]}$.

Bakteri Propionibacterium acnes merupakan salah satu bakteri gram positif serta agen utama penyebab terjadinya inflamasi jerawat. Propionibacterium acnes merangsang pelepasan IL-1, IL-8, TNF-, dan mengaktifkan sistem komplemen ${ }^{[2]}$. Pengobatan jerawat yang dilakukan di klinik kulit, biasanya diberikan antibiotik yang dapat membunuh bakteri dan menghambat inflamasi, contohnya tetrasiklin, eritromisin. Sementara itu penggunaan obat antibiotik dalam jangka panjang selain dapat menimbulkan resistensi juga dapat menimbulkan kerusakan organ dan imuno hipersensitivitas.

Salah satu tanaman obat yang memiliki efek antijerawat adalah daun binahong (Anredera cordifolia (Ten) Steenis. Kandungan metabolit sekunder daun binahong meliputi flavonoid, saponin, alkaloid, polifenol, dan monopolisakarida termasuk L-arabinosa, D-galaktose, Lrhamnosa. Daun binahong memiliki aktivitas antioksidan, asam askorbat, dan senyawa fenolik dan senyawa tersebut 
memiliki kemampuan untuk melawan bakteri gram positif dan gram negatif ${ }^{[3]}$.

Sebelumnya telah dilakukan penelitian tentang daun binahong yang memberikan hasil bahwa ekstrak daun binahong memiliki aktivitas antibakteri terhadap Propionbacterium acnes dan Staphylococcus epidermis. Pada hasil uji bioautografi menunjukkan bahwa senyawa yang berperan aktif sebagai antibakteri dalam daun binahong terhadap bakteri propionibacterium acnes diduga adalah senyawa flavonoid ${ }^{[4]}$. Menurut penelitian yang dilakukan oleh Khunaifi, Konsentrasi Hambat Minimum (KHM) ekstrak daun Binahong pada bakteri Staphylococcus aureus pada konsentrasi $25 \%{ }^{[5]}$.

Pada penelitian ini, peneliti akan melakukan formulasi salep ekstrak daun binahong dengan basis PEG dan dilakukan uji aktivitas terhadap bakteri penyebab jerawat Propionibacterium acnes.

\section{Metode Penelitian}

Jenis penelitian yang digunakan adalah penelitian eksperimental dengan rancangan penelitian Post Test Control Group Design Only. Penelitian ini dimulai dengan determinasi tanaman, pengumpulan dan pengolahan daun binahong, pembuatan ekstrak dari daun binahong, formulasi salep, dan uji aktivitas terhadap bakteri Propionibacterium acnes, analisis data menggunakan One Way ANOVA.

\section{Alat dan Bahan}

Bahan yang digunakan dalam penelitian ini daun binahong yang diperoleh dari desa Blubuk Kabupaten Tegal, PEG400, PEG-4000, Oleum Citri, Nipagin, Kertas saring, Kertas Cakram.

Alat yang digunakan dalam penelitian ini adalah alat-alat gelas (Pyrex), timbangan analitik, inkubator, autoklaf, stamper dan mortir, cawan petri, ose.

\section{Cara Kerja}

Determinasi dilakukan dengan melihat ciri-ciri tanaman binahong yang diperoleh dari daerah Slawi, Kabupaten Tegal, Jawa Tengah. Hasil determinasi sesuai dengan kunci determinasi Steenis, Tjitrosoepomo.

Daun Binahong (Anredera cordifolia (Ten) Steenis) yang masih segar, dan cukup tua dilakukan sortasi terlebih dahulu.
Setelah itu dilakukan pencucian dengan air mengalir hingga bersih lalu ditiriskan. kemudian dikeringkan dengan cara dijemur dibawah sinar matahari ditutup kain warna hitam hingga berubah menjadi warna coklat.

Simplisia kemudian dihaluskan menggunakan blender. Setelah itu ditimbang berat serbuk keringnya dan disimpan dalam wadah tertutup baik terlindung cahaya matahari.

Pembuatan ekstrak dilakukan dengan metode maserasi yang menggunakan penyari etanol $96 \%$. Serbuk simplisia daun binahong sebanyak 450 gram direndam dengan 4,5 liter etanol 96\%, kemudian diaduk dengan alat electric stirrer selama 3 jam dengan kecepatan $400 \mathrm{rpm}$ dan didiamkan selama 5 hari. Dilakukan penyaringan tahap petama dengan kapas, kemudian untuk penyaringan tahap kedua dengan menggunakan kertas saring. Semua maserat dikumpulkan dipekatkan dengan rotary evaporator suhu $60^{\circ} \mathrm{C}$ dengan kecepatan $50 \mathrm{rpm}$.

Tabel 1. Formula Salep Uji

\begin{tabular}{llcccc}
\hline & \multicolumn{5}{c}{ Formula (\%) } \\
\cline { 2 - 6 } No. & $\begin{array}{l}\text { Nama } \\
\text { Bahan }\end{array}$ & FI & F II & F III & $\begin{array}{c}\text { Kontrol } \\
\text { Negatif }\end{array}$ \\
\hline 1. Ekstrak & 25 & 30 & 35 & - \\
& daun & & & & \\
& binahong & & & & \\
2. & PEG-4000 & 29 & 26 & 23 & 40 \\
3. PEG-400 & 45 & 43 & 41 & 59 \\
4. & Nipagin & 0,18 & 0,18 & 0,18 & 0,18 \\
5. & Oleum & qs & qs & qs & qs \\
& Citri & & & & \\
\hline
\end{tabular}

Salep dibuat dengan cara melarutkan nipagin kedalam PEG-400. Kemudian meleburkan PEG-4000 kedalam campuran 1 diaduk sampai dingin. Menambahkan ekstrak daun binahong kedalam campuran 2 lalu diaduk sampai homogen. Menambahkan oleum citri sedikit demi sedikit dalam campuran 3. Salep disimpan dalam pot salep.

Media pertumbuhan dibuat dengan melarutkan NA dalam aquades dengan dipanaskan. Didistribusi sesuai kebutuhan dalam tabung reaksi dan ditutup dengan 
kapas lalu dilapisi plastik. Selanjutnya di sterilisasi dalam autoklaf pada suhu $121^{\circ} \mathrm{C}$ dan tekanan 15 lbs selama 15 menit.

Bakteri uji ditumbuhkan pada media nutrient agar dengan cara menggoreskan bakteri dari biakan murni menggunakan jarum ose pada media NA. Bakteri yang sudah digoreskan pada media kemudian diinkubasi pada suhu $37^{\circ} \mathrm{C}$ selama 24 jam. Koloni bakteri uji pada media biakan NA umur 24 jam diambil sebanyak 1-2 ose, kemudian dimasukkan kedalam tabung berisi aquades steril. Suspensi bakteri uji diambil sebanyak $100 \mu 1$, dituang secara merata pada media NA menggunakan metode spread plate ${ }^{[6]}$. Media ditunggu sampai mengeras, lalu diinkubasi selama 24 jam kemudian diletakkan kertas cakram yang sebelumnya telah diolesi salep ekstrak daun binahong dengan konsentrasi $25 \%$, $30 \%, 35 \%$. Kontrol negatif yang digunakan adalah salep yang hanya menggunakan basis tanpa adanya penambahan ekstrak daun binahong.

Media yang sudah berisi bakteri uji, kontrol negatif dan kertas cakram yang telah diolesi salep dengan konsentrasi ekstrak yang berbeda-beda, diinkubasi pada suhu 37 ${ }^{0} \mathrm{C}$ selama 24-48 jam, kemudian hasil zona bening diukur dengan jangka sorong. Uji dilakukan dengan 3 kali replikasi.

\section{Hasil dan Pembahasan}

Hasil determinasi tanaman binahong diperoleh :

1b, 2b, 3b, 4b, 6b, 7b, 9a, 41b, 42b, 43b, $54 \mathrm{~b}, \quad 59 \mathrm{~b}, 61 \mathrm{~b}, 62 \mathrm{~b}, 63 \mathrm{a}, 64 \mathrm{~b}$, .......................................mam: Basellaceae 1b, .................................................. Anredera

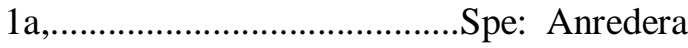
cordifolia (Tenore.) Steen.

Ekstrak etanol yang dihasilkan dari daun binahong adalah ekstrak kental warna hijau pekat, seberat $107,9 \mathrm{~g}$ dengan rendemen $23,97 \%$.

Berdasarkan uji aktivitas, terlihat adanya daerah bening yang disekitar kertas cakram, daerah bening tersebut merupakan daerah hambat salep ekstrak etanol daun binahong terhadap pertumbuhan bakteri Propionibacterium acnes.

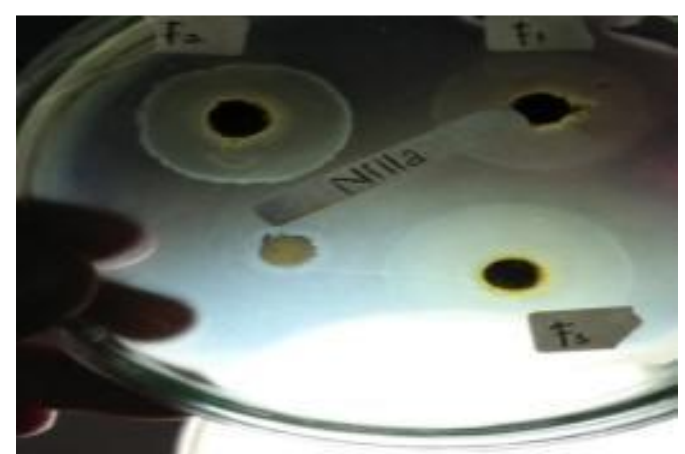

Gambar 1. Zona Hambat Salep Ekstrak Binahong

Uji aktivitas antibakteri salep ekstrak daun binahong menghasilkan urutan formulasi yang memiliki zona hambat paling besar pada formula 3 dengan diameter rata-rata zona hambat $22 \mathrm{~mm}$, kemudian formula 2 dengan diameter ratarata zona hambat 19,6 $\mathrm{mm}$ dan yang terakhir formula 1 dengan diameter rata-rata zona hambat 17,8 $\mathrm{mm}$. Pengukuran diameter zona hambat menunjukkan bahwa salep ekstrak etanol daun binahong memiliki daya hambat kuat sampai sangat kuat terhadap bakteri Propionibacterium acnes. Penentuan kriteria daya hambat berdasarkan literatur Davis dan Stout yang menyatakan bahwa kriteria daya antibakteri sebagai berikut : daerah hambatan $20 \mathrm{~mm}$ atau lebih termasuk sangat kuat, daerah hambatan 10$20 \mathrm{~mm}$ kategori kuat, daerah hambatan 5-10 mm kategori sedang, dan daerah hambatan 5 $\mathrm{mm}$ atau kurang termasuk kategori lemah ${ }^{[7]}$. Tabel 2. Hasil Uji Zona Hambat Salep

\begin{tabular}{cccc}
$\begin{array}{c}\text { Zona } \\
\text { Hambat }\end{array}$ & $\mathrm{N}$ & $\begin{array}{c}\text { Rata-rata } \pm \text { SD } \\
(\mathrm{mm})\end{array}$ & $\mathrm{P}$ \\
\hline $\mathrm{F} 1$ & 3 & $17.8333 \pm 4.25245$ & 0.000 \\
$\mathrm{~F} 2$ & 3 & $19.6667 \pm 3.32916$ & \\
$\mathrm{~F} 3$ & 3 & $22.0000 \pm 4.27200$ & \\
Basis & 3 & $.0000 \pm .00000$ & \\
\hline
\end{tabular}

Hasil pengujian menunjukkan bahwa, diameter zona hambat cenderung meningkat sebanding dengan meningkatnya konsetrasi ekstrak. Berdasarkan hasil perhitungan analisis One-way Anova pada tabel dibawah, dengan tingkat kepercayaan $95 \%(\alpha=5 \%)$ diperoleh nilai signifikan $0,000<0,05$, sehingga dapat disimpulkan terdapat perbedaan bermakna zona hambat, dari masing-masing formula salep. Pada uji lanjut menggunakan uji Post Hoc untuk 
membandingkan zona hambat perlakuan antar kelompok uji dengan nilai signifikansi seperti pada tabel dibawah ini.

Tabel 3. Hasil Uji Lanjut Post Hoc Zona Hambat Salep Ekstrak Etanol Daun Binahong

\begin{tabular}{cccl}
\hline Formula & $\begin{array}{c}\text { Perbedaan } \\
\text { Rerata }\end{array}$ & Sig. \\
\hline 1 & 2 & -1.83333 & 1.000 \\
& 3 & -4.16667 & 1.000 \\
& Basis & $17.83333^{*}$ & 0.001 \\
2 & 1 & 1.83333 & 1.000 \\
& 3 & -2.33333 & 1.000 \\
& Basis & $19.66667^{*}$ & 0.001 \\
3 & 1 & 4.16667 & 1.000 \\
& 2 & 2.33333 & 1.000 \\
& Basis & $22.00000^{*}$ & 0.000 \\
Basis & 1 & $-17.83333^{*}$ & 0.001 \\
& 2 & $-19.66667^{*}$ & 0.001 \\
& 3 & $-22.00000^{*}$ & 0.000 \\
\hline
\end{tabular}

Keterangan :

(*) : Terdapat Perbedaan Bermakna

Hasil uji lanjut Post Hoc menunjukkan ada perbedaan bermakna aktivitas antibakteri antara basis dengan formula 1, formula 2, formula 3 karena $\mathrm{P}<0.05$.

Aktivitas antibakteri salep ekstrak etanol daun binahong diduga karena adanya senyawa-senyawa yang memiliki mekanisme antibakteri diantaranya, Flavonoid memiliki aktivitas antibakteri melalui hambatan fungsi DNA girase sehingga kemampuan replikasi bakteri dihambat, senyawa ini kontak dengan DNA pada inti sel bakteri, adanya perbedaan kepolaran antara lipid penyusun DNA dengan gugus alkohol pada senyawa flavonoid menyebabkan kerusakan struktur lipid DNA bakteri sehingga bakteri akan lisis dan mati ${ }^{[8]}$. Alkaloid sebagai antibakteri dengan mekanisme mengganggu komponen penyusun peptidoglikan pada sel bakteri sehingga lapisan dinding sel tidak terbentuk secara utuh dan menyebabkan kematian sel ${ }^{[9]}$. Polifenol pada daun binahong juga memiliki akivitas antibakteri, mekanisme kerja polifenol sebagai antibakteri yaitu dengan mengganggu fungsi enzim dan substratnya, sehingga lambat laun akan mengakibatkan kematian sel ${ }^{[10]}$.
Kandungan daun binahong lainnya adalah saponin. Mekanisme kerja saponin termasuk dalam kelompok antibakteri yang mengganggu permeabilitas membran sel bakteri, yang mengakibatkan kerusakan membran sel dan menyebabkan keluarnya berbagai komponen penting dari dalam sel antibakteri yaitu protein, asam nukleat, dan nukleotida, sehingga bakteri akan lisis ${ }^{[11]}$.

\section{Kesimpulan}

Salep ekstrak Binahong konsentrasi 25\%, 30\% dan 35\% memiliki aktivitas antibakteri terhadap bakteri Propionibacterium acnes. Hasil pengukuran diameter zona hambat menunjukkan bahwa salep ekstrak etanol daun binahong memiliki kriteria daya hambat yang kuat sampai sangat kuat terhadap bakteri Propionibacterium acne.

\section{Daftar Pustaka}

[1] Sawarkar, H.A, Khadabadi, S.S., Mankar, D.M., Farooqui, I.A., Jagtap, N.S., 2010.Development and Biological Evaluation Of Herbal Antiacne Gel. International Journal of PharmTech Research,2(3): 2028-2029

[2] Khan, Z.Z, Assi M., Moore, T.A. 2009. Recurent Epidural Abcess Caused by Propionibacterium acnes. Khansas Journal of Medicine:92-95

[3] Astuti, Sri Murni., Sakinah A.M, Mimi., Andayani B.M, Retno., Risch, Awalludin. 2011. Determination

[4] Prijayanti,A.J. 2011. Uji Aktivitas Antibakteri Fraksi Daun Binahong (Anredera Cordifolia (Tenore) Steen) Terhadap Propionobacterium acnes ATCC 6919 dan Staphylococcus epidermidis FNCC 0048. Skripsi. Fakultas MIPA. Yogyakarta: Universitas Islam Indonesia.

[5] Khunaifi, Muhid. 2012. Uji Aktifitas Antibakteri Ekstrak Daun Binahong (Anredera Cordifolia (Ten) Steenis) Terhadap Bakteri Staphylococcus aureus dan Psedomonas aeruginosa. Skripsi. Sains dan Teknologi. Malang: UIN Maulana Malik Ibrahim.

[6] Aziz, S. 2010. Uji Aktivitas Antibakteri Ekstrak Etanol Daun dan Umbi Bakung Putih (Crinum asiaticum L) Terhadap 
Bakteri Penyebab Jerawat. Skripsi. Program Studi Farmasi. Fakultas Kedokteran dan Ilmu Kesehatan. Jakarta: UIN Syarif Hidayatullah.

[7] Davis, W. W., T. R. Stout. 1971. Disc Plate Methods of Microbiological Antibiotic Assay. Applied Microbiology

[8] Wulandari P, Suswati E, Misnawi, Rainul A. 2012. Efek Antibakteri Ekstrak Etanol Biji Kakao (T. cacao) terhadap Pertumbuhan Shigella Dysentriae secara In vitro. Jurnal Medika Planta, 1(5): 67-7.

[9] Darsana. 2012. Potensi Daun Binahong (Anredera cordifolia (Ten) Steenis) dalam Menghambat Pertumbuhan Bakteri Escherishia coli Secara In Vitro. Indonesia Medicus Veterinus, 1(3): 337-351.

[10] Fitrianti, D., Noorhamdani, A.S., Karyono, S.S. 2011. Efektivitas Ekstrak Daun Ceplukan sebagai Antimikroba terhadap Methicillinresistant Staphylococcus aureus In Vitro. Jurnal Kedokteran Brawijaya, 26(4): 212-215

[11] Wayan FA, Betta K I. 2015. Binahong (Cassia Alata L) For Inhibiting The Growth Of Bacteria Escherichia Coli. J Majority,4(4) 